\title{
Gambaran status gizi anak 12-24 bulan di Puskesmas Mergangsan Kota Yogyakarta tahun 2015: tinjauan riwayat pemberian ASI eksklusif dan kejadian penyakit infeksi
}

Nutritional status description of children aged 12-24 months: judging from the history of exclusive breastfeeding and infectious diseases at the Mergangsan Health Center Yogyakarta 2015

Nurlisa T.Hi.Abdullah ${ }^{1}$, Yhona Paratmanitya ${ }^{2}$, Febrina Suci Hati ${ }^{3}$

\begin{abstract}
Background: Malnutrition and severe undernutrition is one of the main health problems faced in developing countries. In Indonesia, health problems and the child's growth are influenced by two main issues, namely a state of good nutrition and the prevalence of infectious diseases. Worsening child malnutrition can occur because of ignorance of the mother about the manner of breastfeeding to their children. Yogyakarta city still has the highest prevalence of malnutrition $(W / A)$, as compared to four other districts in the amount of $1.04 \%$ (exceeding the target of the action plan for food and nutrition is < $1 \%$ ).

Objectives: To know the nutritional status of children (12-24 months) in terms of the history of exclusive breastfeeding and the incidence of infectious diseases at the Mergangsan health center in Yogyakarta.

Methods: This research used quantitative descriptive method with cross sectional approach. Subjects were children aged 12-24 who months were recorded in four villages Kaparakan Integrated Health Centre (RW III , VII , IX, and XII) in Puskesmas Mergangsan, Yogyakarta. The sampling technique of this study used total sampling, the number of samples were 34 respondents. Data were collected by using a questionnaire.

Results: Most children did not receive exclusive breastfeeding (55.9\%). All of the children had infectious diseases (diarrhea, respiratory infection) in the last one month. Most of children had good nutrition (58.8\%), and $86.7 \%$ children received exclusive breastfeeding. Meanwhile, $36.8 \%$ children did not. Most of children who had infectious diseases history were included in good nutritional status.

Conclusion: Children who had a history of exclusive breastfeeding was $86.7 \%$, while those who had not breastfeeding exclusively was $36.8 \%$. Most of children with good nutritional status had experiences of infectious diseases (diarrhea, respiratory infection).
\end{abstract}

KEYWORDS: exclusive breastfeeding, infectious disease, nutritional status

\begin{abstract}
ABSTRAK
Latar belakang: Gizi kurang dan buruk merupakan salah satu masalah kesehatan utama yang dihadapi oleh negara berkembang. Di Indonesia, masalah kesehatan dan pertumbuhan anak sangat dipengaruhi oleh dua persoalan utama yaitu keadaan gizi yang tidak baik dan merajalelanya penyakit infeksi. Memburuknya gizi anak dapat terjadi karena ketidaktahuan ibu mengenai tata cara pemberian ASI kepada anaknya. Kota Yogyakarta masih memiliki prevalensi gizi buruk tertinggi (BB/U) dibandingkan empat kabupaten lainnya, yaitu sebesar 1,04\% (melebihi target rencana aksi daerah pangan dan gizi yaitu <1\%).
\end{abstract}

\footnotetext{
${ }^{1}$ Prodi Kebidanan Sekolah Tinggi IImu Kesehatan Alma Ata Yogyakarta, Jl. Ringroad Barat Daya no 1, Tamantirto, Yogyakarta, Telp (0274) 4342288, 4342270

2 Prodi Gizi Sekolah Tinggi IImu Kesehatan Alma Ata Yogyakarta, Jl. Ringroad Barat Daya no 1, Tamantirto, Yogyakarta, Telp (0274) 4342288, 4342270

${ }^{3}$ Prodi Kebidanan Sekolah Tinggi IImu Kesehatan Alma Ata Yogyakarta, Jl. Ringroad Barat Daya no 1, Tamantirto, Yogyakarta, Telp (0274) 4342288, 4342270
} 
Tujuan: Mengetahui gambaran status gizi anak (12-24 bulan) ditinjau dari riwayat pemberian ASI eksklusif dan kejadian penyakit infeksi di Puskesmas Mergangsan Kota Yogyakarta.

Metode: Penelitian ini menggunakan metode deskriptif kuantitatif dengan pendekatan cross sectional. Subjek penelitian adalah anak usia 12-24 bulan yang tercatat di 4 Posyandu Kelurahan Kaparakan (RW III, VII, IX, dan XII) di wilayah kerja Puskesmas Mergangsan, Kota Yogyakarta. Teknik pengambilan sampel pada penelitian ini menggunakan total sampling, dengan jumlah sampel 34 responden. Alat ukur dalam penelitian ini menggunakan kuesioner.

Hasil: Sebagian besar anak tidak mendapat ASI eksklusif (55,9\%). Semua anak pernah mengalami penyakit infeksi (diare, ISPA) dalam 1 bulan terakhir. Mayoritas anak memiliki gizi baik $(58,8 \%)$ dengan jumlah anak yang mendapat ASI eksklusif sebesar $86,7 \%$, sedangkan yang tidak mendapat ASI ekslusif sebesar 36,8\%. Mayoritas anak yang pernah mengalami penyakit infeksi berstatus gizi baik (58,8\%).

Kesimpulan: Sebagian besar anak memiliki riwayat pemberian ASI eksklusif. Terdapat lebih dari sebagian anak dengan status gizi baik pernah mengalami penyakit infeksi (diare, ISPA).

KATA KUNCI: ASI eksklusif, penyakit infeksi, status gizi

\section{PENDAHULUAN}

Masalah gizi kurang dan gizi buruk merupakan salah satu masalah kesehatan utama yang terutama dihadapi oleh negara berkembang. Di Indonesia, sebagaimana halnya negara-negara berkembang lainnya, masalah kesehatan dan pertumbuhan anak dipengaruhi oleh dua persoalan utama yaitu keadaan gizi yang tidak baik dan merajalelanya penyakit infeksi (1).

Berdasarkan hasil pemantauan status gizi di DIY tahun 2012, prevalensi balita gizi buruk sebesar 0,59\% (mengalami penurunan sebesar 0,095\% dibandingkan angka prevalensi tahun 2011 yaitu $0,64 \%$ ). Anak yang kurang gizi mengalami penurunan interaksi dengan lingkungannya. Keadaan ini akan berpengaruh terhadap perkembangan anak yang buruk (2). Memburuknya gizi anak dapat saja terjadi karena ketidaktahuan ibu mengenai tata cara pemberian ASI kepada anaknya. Anak berusia di bawah 3 tahun yang tidak memperoleh ASI eksklusif berisiko 3,58 kali mengalami gizi buruk dibandingkan dengan anak yang memperoleh ASI ekslusif (1). Pencapaian ASI ekslusif di Kota Yogyakarta masih jauh dari target yang diharapkan yaitu masih $43,37 \%$ (2).

Kota Yogyakarta masih memiliki prevalensi gizi buruk tertinggi (BB/U) dibandingkan dengan empat kabupaten lainnya yaitu sebesar 1,04\% (melebihi target rencana aksi daerah pangan dan gizi yaitu <1\%). Di Kota Yogyakarta, Kecamatan Mergangsan merupakan satu-satunya kecamatan dengan prevalensi gizi buruk tertinggi yaitu sebesar $>3 \%$ (2). Survei pendahuluan di Puskesmas Mergangsan membuktikan bahwa dari populasi sebanyak 120 bayi usia 12-24 bulan, terdapat 9 kasus bayi gizi kurang, 4 kasus bayi gizi buruk, 3 kasus gizi lebih, dan 104 bayi gizi baik. Tujuan umum dari penelitian ini yaitu untuk mengetahui gambaran status gizi anak (12-24 bulan) ditinjau dari riwayat pemberian ASI eksklusif dan kejadian penyakit infeksi di Puskesmas Mergangsan tahun 2015.

\section{BAHAN DAN METODE}

Penelitian ini menggunakan metode deskriptif kuantitatif dengan pendekatan cross sectional. Penelitian dilaksanakan pada bulan Juni tahun 2015. Variabel bebas dalam penelitian ini adalah status gizi dan variabel terikatnya yaitu riwayat pemberian ASI eksklusif dan kejadian penyakit infeksi. Subjek penelitian adalah anak usia 1224 bulan yang tercatat di 4 Posyandu Kelurahan Kaparakan (RW III, VII, IX, dan XII) di wilayah kerja Puskesmas Mergangsan Kota Yogyakarta. Teknik pengambilan sampel pada penelitian ini menggunakan total sampling, dengan jumlah sampel 37 responden. Di antara jumlah tersebut, 3 responden dikeluarkan karena 2 responden tidak bersedia dan 1 responden sedang tidak berada di tempat. Instrumen penelitian adalah kuesioner yang berisi pertanyaan dan pengukuran berat badan subjek dengan timbangan bayi dengan ketelitian 
$0,1 \mathrm{~kg}$, kapasitas $20 \mathrm{~kg}$ dan untuk mengukur status gizi digunakan rumus z-score.

\section{HASIL}

Karakteristik responden berdasarkan usia, pendidikan, dan pekerjaan ibu, serta jenis kelamin dan usia anak

Berdasarkan Tabel 1 dapat dilihat bahwa usia ibu sebagian besar berada pada rentang 20-30 tahun dengan jumlah 21 orang $(61,8 \%)$. Ibu berlatar belakang pendidikan terakhir terbanyak adalah SMA sebanyak 28 orang $(82,4 \%)$, dan mayoritas memiliki pekerjaan yaitu sebanyak 22 orang $(64,7 \%)$. Dari distribusi anak balita menurut jenis kelamin, terlihat bahwa mayoritas adalah anak perempuan yaitu sebanyak 21 orang $(38,2 \%)$ dan menurut usia terlihat kelompok usia 12-18 bulan merupakan kelompok usia terbanyak yaitu sebanyak 25 orang $(73,5 \%)$.

Tabel. 1 Distribusi frekuensi karakteristik responden dan keluarga responden berdasarkan usia, pendidikan, pekerjaan serta jenis kelamin dan usia anak

\begin{tabular}{lcc}
\hline Karakteristik & $\mathbf{n}$ & $\%$ \\
\hline Usia ibu (tahun) & 2 & 5,9 \\
$\quad<20$ & 21 & 61,8 \\
$20-30$ & 11 & 32,4 \\
$\quad>30$ & & \\
Pendidikan ibu & 0 & 0 \\
$\quad$ SD & 3 & 8,8 \\
SMP & 28 & 82,4 \\
SMA & 3 & 8,8 \\
Perguruan tinggi & & \\
Pekerjaan ibu & 22 & 64,7 \\
$\quad$ Bekerja & 12 & 35,3 \\
$\quad$ Tidak bekerja & & \\
Jenis kelamin anak & 13 & 38,2 \\
Laki-laki & 21 & 61,8 \\
$\quad$ Perempuan & & \\
Usia anak (bulan) & 25 & 73,5 \\
12-18 & 9 & 26,5 \\
19-24
\end{tabular}

Berdasarkan Tabel 2, data hasil pengukuran antropometri menggunakan indeks BB/ $\mathrm{U}$, mayoritas anak memiliki satus gizi baik yaitu sebesar $58,8 \%$.
Tabel 2. Distribusi frekuensi status gizi anak menurut indeks $B B / U$

\begin{tabular}{lcc}
\hline \multicolumn{1}{c}{ Status gizi } & $\mathbf{n}$ & $\%$ \\
\hline Lebih & 1 & 2,9 \\
Baik & 20 & 58,8 \\
Kurang & 10 & 29,4 \\
Buruk & 3 & 8,8 \\
Total & 34 & 100,0 \\
\hline
\end{tabular}

\section{Distribusi frekuensi riwayat pemberian ASI eksklusif pada anak}

Berdasarkan hasil penelitian yang telah dilakukan di Posyandu Wilayah Kerja Puskesmas Mergangsan dengan jumlah sampel sebanyak 34 anak, didapatkan hasil tentang riwayat pemberian ASI eksklusif seperti pada Tabel 3.

Tabel 3. Distribusi frekuensi riwayat pemberian ASI eksklusif pada anak

\begin{tabular}{lcc}
\hline \multicolumn{1}{c}{ Riwayat pemberian ASI } & $\mathbf{n}$ & \% \\
\hline ASI eksklusif & 15 & 44,1 \\
Tidak ASI eksklusif & 19 & 55,9 \\
Total & 34 & 100,0 \\
\hline
\end{tabular}

Tabel 3 menunjukkan bahwa sebagian besar anak tidak mendapatkan ASI ekslusif saat usia 0-6 bulan yaitu sebanyak 19 anak (55,9\%).

\section{Distribusi frekuensi kejadian penyakit infeksi pada anak}

Tabel 4 menunjukkan bahwa sebanyak 34 anak (100\%) pernah mengalami penyakit infeksi (diare, ISPA) dalam 1 (satu) bulan terakhir. Kejadian penyakit infeksi lebih sering terjadi pada kelompok usia 1-2 tahun. Tingginya angka kejadian pada kelompok ini disebabkan kekebalan alami pada anak di bawah usia 24 bulan belum terbentuk, sehingga memungkinkan terjadinya infeksi lebih besar.

Tabel 4. Distribusi frekuensi kejadian penyakit infeksi pada anak

\begin{tabular}{ccc}
\hline $\begin{array}{c}\text { Kejadian penyakit } \\
\text { infeksi }\end{array}$ & $\mathbf{n}$ & \% \\
\hline Ya & 34 & 100 \\
Tidak & 0 & 0 \\
Total & 34 & 100 \\
\hline
\end{tabular}


Distribusi frekuensi status gizi berdasarkan riwayat pemberian ASI eksklusif

Berdasarkan Tabel 5 diketahui bahwa persentase status gizi baik lebih tinggi pada anak yang diberi ASI eksklusif (86,7\%) dibandingkan dengan yang tidak diberi ASI eksklusif $(36,8 \%)$. Sementara itu, terdapat 1 anak yang mendapatkan ASI eksklusif saat usia 0-6 bulan dan mengalami gizi buruk.

Distribusi frekuensi status gizi berdasarkan kejadian penyakit infeksi

Dari Tabel 6 diketahui bahwa 58,8\% anak dengan status gizi baik pernah mengalami penyakit infeksi (diare,ISPA). Persentase kejadian penyakit infeksi lebih tinggi pada kelompok yang berstatus gizi baik.

\section{BAHASAN}

Karakteristik responden berdasarkan usia, pendidikan, pekerjaan, serta jenis kelamin dan usia anak

Tabel 2 menunjukkan bahwa status gizi berdasarkan hasil pengukuran antropometri menggunakan indeks $\mathrm{BB} / \mathrm{U}$, mayoritas balita memiliki gizi baik yaitu sebanyak 20 anak $(58,8 \%)$. Status gizi adalah suatu keadaan kesehatan sebagai akibat keseimbangan antara konsumsi, penyerapan zat gizi dan penggunaannya di dalam tubuh (3). Status gizi menggambarkan baik buruknya konsumsi zat gizi seseorang. Zat gizi sangat dibutuhkan untuk pembentukan zat-zat kekebalan tubuh seperti antibodi. Semakin baik zat gizi yang dikonsumsi, berarti semakin baik status gizinya dan semakin baik juga kekebalan tubuhnya. Status gizi baik terjadi bila tubuh memperoleh cukup zat-zat gizi yang digunakan secara efisien, sehingga memungkinkan pertumbuhan fisik, perkembangan otak, kemampuan kerja, dan kesehatan secara umum pada tingkat setinggi mungkin (4).

\section{Distribusi frekuensi riwayat pemberian ASI eksklusif pada anak}

Tabel 3 menunjukkan bahwa sebagian besar anak tidak mendapatkan ASI eksklusif saat usia 0-6 bulan, yaitu sebanyak 19 anak $(55,9 \%)$. Pemberian ASI sangat mempengaruhi pertumbuhan dan perkembangan bayi usia 0-6 bulan, sehingga bayi dengan pemberian ASI yang kurang akan mengalami gangguan pada pertumbuhan dan perkembanganya (5). Selain mengandung zat gizi yang sesuai, ASI juga mengandung enzim-enzim untuk mencerna zat-zat gizi yang terdapat dalam ASI. Zat-zat gizi berkualitas tinggi tersebut berguna untuk pertumbuhan dan perkembangan anak (6).

\section{Distribusi frekuensi kejadian penyakit infeksi pada anak}

Tabel 4 menunjukkan bahwa berdasarkan hasil penelitian didapatkan sebanyak 34 anak (100\%) pernah mengalami penyakit infeksi (diare,

Tabel 5. Distribusi frekuensi status gizi berdasarkan pemberian ASI eksklusif

\begin{tabular}{|c|c|c|c|c|c|c|c|c|c|c|}
\hline \multirow{3}{*}{$\begin{array}{c}\text { Pemberian } \\
\text { ASI }\end{array}$} & \multicolumn{8}{|c|}{ Status gizi } & \multirow{2}{*}{\multicolumn{2}{|c|}{ Total }} \\
\hline & \multicolumn{2}{|c|}{ lebih } & \multicolumn{2}{|c|}{ baik } & \multicolumn{2}{|c|}{ kurang } & \multicolumn{2}{|c|}{ buruk } & & \\
\hline & $\mathbf{n}$ & $\%$ & $\mathbf{n}$ & $\%$ & $n$ & $\%$ & $\mathbf{n}$ & $\%$ & $n$ & $\%$ \\
\hline ASI eksklusif & 0 & 0 & 13 & 86,7 & 1 & 6,7 & 1 & 6,7 & 15 & 100 \\
\hline Non eksklusif & 1 & 5,3 & 7 & 36,8 & 9 & 47,4 & 2 & 10,5 & 19 & 100 \\
\hline Total & 1 & 2,9 & 20 & 58,8 & 10 & 29,4 & 3 & 8,8 & 34 & 100 \\
\hline
\end{tabular}

Tabel 6. Distribusi frekuensi status gizi berdasarkan kejadian penyakit infeksi

\begin{tabular}{|c|c|c|c|c|c|c|c|c|c|c|}
\hline \multirow{3}{*}{$\begin{array}{c}\text { Kejadian } \\
\text { penyakit infeksi }\end{array}$} & \multicolumn{8}{|c|}{ Status gizi } & \multirow{2}{*}{\multicolumn{2}{|c|}{ Total }} \\
\hline & \multicolumn{2}{|c|}{ lebih } & \multicolumn{2}{|c|}{ baik } & \multicolumn{2}{|c|}{ kurang } & \multicolumn{2}{|c|}{ buruk } & & \\
\hline & $n$ & $\%$ & $\mathbf{n}$ & $\%$ & $n$ & $\%$ & $\mathbf{n}$ & $\%$ & $n$ & $\%$ \\
\hline $\mathrm{Ya}$ & 1 & 2,9 & 20 & 58,8 & 10 & 29,4 & 3 & 8,8 & 34 & 100 \\
\hline Tidak & 0 & 0 & 0 & 0 & 0 & 0 & 0 & 0 & 0 & 0 \\
\hline Total & 1 & 2,9 & 20 & 58,8 & 10 & 29,4 & 3 & 8,8 & 34 & 100 \\
\hline
\end{tabular}


ISPA) dalam 1 (satu) bulan terakhir. Kejadian penyakit infeksi lebih sering terjadi pada kelompok usia 1-2 tahun. Tingginya angka kejadian pada kelompok ini disebabkan kekebalan alami pada anak di bawah usia 24 bulan belum terbentuk, sehingga memungkinkan terjadinya infeksi lebih besar. Usia di bawah 2 tahun merupakan peralihan dari ASI ke makanan pendamping ASI atau makanan sapihan. Makanan pendamping ASI maupun makanan sapihan seringkali memiliki kandungan karbohidrat tinggi, tetapi mutu dan kandungan proteinnya sangat rendah (7).

Frekuensi dan durasi terjadinya penyakit infeksi dapat mempengaruhi status gizi balita. Hal ini didukung oleh penelitian sebelumnya yang menyatakan bahwa status gizi dapat mempengaruhi kadar seng (Zn) serum di dalam tubuh serta durasi penyembuhan diare. Semakin baik status gizi pada penderita diare akut, semakin pendek durasi diare dan kejadian dehidrasi semakin rendah (8).

\section{Distribusi frekuensi status gizi berdasarkan riwayat pemberian ASI eksklusif}

Berdasarkan Tabel 5 diketahui bahwa persentase status gizi baik lebih tinggi pada anak yang diberi ASI eksklusif $(86,7, \%)$ dibandingkan dengan yang tidak diberi ASI eksklusif $(36,8 \%)$. $\mathrm{Hal}$ ini sejalan dengan penelitian sebelumnya yang menyatakan bahwa ada hubungan antara pemberian ASI eksklusif dengan status gizi balita usia 6-24 bulan. Ibu yang memberikan ASI eksklusif akan semakin baik status gizi balitanya dibanding ibu yang tidak memberikan ASI eksklusif kepada balita yang berusia 6-24 bulan (9). Namun demikian, pada penelitian di Kabupaten Timur Tengah Selatan, Nusa Tenggara Timur tidak ditemukan hubungan antara pemberian ASI eksklusif dengan kejadian stunting pada anak berumur di bawah 2 tahun. Hal ini disebabkan pengetahuan ibu yang rendah tentang ASI serta rendahnya kualitas pemberian ASI (10).

Bayi yang tidak mendapatkan ASI eksklusif tidak mendapatkan kandungan nutrisi dalam ASI secara penuh, sehingga kekebalan tubuhnya akan lebih rendah yang berdampak lebih mudah terserang penyakit yang nantinya akan mempengaruhi status gizi bayi. Asumsi ini dilatarbelakangi oleh teori yang menyatakan bahwa kandungan gizi dan komposisi ASI sangat penting bagi kesehatan bayi. Seorang bayi yang diberikan ASI akan memperoleh manfaat untuk kesehatannya, antara lain akan memiliki kekebalan atau daya tahan tubuh yang baik sehingga terlindungi dari berbagai macam penyakit seperti infeksi, virus, dan jamur (11).

\section{Distribusi frekuensi status gizi berdasarkan kejadian penyakit infeksi}

Hubungan gizi dengan penyakit infeksi akan lebih terlihat jika frekuensi dan durasi sakit ikut diteliti, tetapi dalam penelitian ini tidak dikaji durasi dan frekuensi sakit. Hasil penelitian ini berbeda dengan teori yang menyatakan bahwa anak-anak yang mengalami penyakit infeksi sangat mudah mengalami penurunan status gizi (12). Demikian pula penelitian sebelumnya yang menyatakan bahwa kejadian ISPA dan diare dapat mempengaruhi status gizi balita (13-15).

Status gizi buruk berdampak terhadap menurunnya produksi zat antibodi dalam tubuh. Penurunan zat antibodi ini mengakibatkan mudahnya bibit penyakit masuk ke dalam dinding usus dan mengganggu produksi beberapa enzim pencernaan makanan dan selanjutnya penyerapan zat-zat gizi yang penting menjadi terganggu. Keadaan ini dapat memperburuk status gizi anak (16). Balita dengan gizi yang kurang akan lebih mudah terserang penyakit bahkan serangannya lebih lama dibandingkan balita dengan gizi normal karena faktor daya tahan tubuh yang kurang (17).

\section{KESIMPULAN DAN SARAN}

Mayoritas anak tidak mendapatkan ASI eksklusif saat usia 0-6 bulan yaitu sebanyak 19 anak (55,9\%). Sebanyak 34 anak (100\%) pernah mengalami penyakit infeksi (diare, ISPA) dalam 1 (satu) bulan terakhir. Status gizi berdasarkan hasil pengukuran antropometri menggunakan indeks $\mathrm{BB} / \mathrm{U}$, mayoritas balita memiliki gizi baik yaitu sebanyak 20 anak (58,8\%). Anak yang diberi ASI eksklusif memiliki gizi baik sebesar $86,7 \%$ sedangkan yang tidak diberi ASI ekslusif memiliki gizi baik sebesar $36,8 \%$. Sebanyak $58,8 \%$ anak 
dengan status gizi baik pernah mengalami penyakit infeksi (diare, ISPA).

Bagi tenaga kesehatan, diharapkan agar lebih meningkatkan promosi kesehatan tentang gizi balita melalui pemberian pendidikan kesehatan dalam bentuk penyuluhan mengenai pentingnya ASI eksklusif bagi bayi. Bagi ibu, diharapkan agar lebih memperhatikan asupan gizi bagi balitanya serta memberikan ASI pada bayinya secara eksklusif dan dilanjutkan sampai usia 2 (dua) tahun. Bagi peneliti selanjutnya, hendaknya hasil penelitian ini dapat dijadikan sebagai salah satu referensi untuk peneliti selanjutnya, tentunya dengan mempertimbangkan faktor keterbatasan dari penelitian ini. Penelitian selanjutnya dapat dilakukan dengan memasukkan karakteristik responden yang dapat menyebabkan terjadinya penyakit infeksi serta frekuensi sakit.

\section{RUJUKAN}

1. Departemen Kesehatan, Republik Indonesia. Laporan pencapaian tujuan pembangunan millenium indonesia. Jakarta: DepKes R.I. 2010.

2. Dinas Kesehatan, DIY. Peta situasi gizi DIY tahun 2012.

3. Supariasa D, Bakri B, Fajar I. Penilaian status gizi. Jakarta: Penerbit Buku Kedokteran EGC. 2002.

4. Almatsier, S. Prinsip dasar ilmu gizi. cetakan 4 Jakarta: PT Gramedia Pustaka Utama. 2006.

5. Yogi E. Pengaruh pola pemberian ASI dan pola makanan pendamping ASI terhadap status gizi bayi usia 6-12 bulan. Jurnal Delima Harapan . 2013; (2) 1: 14-8.

6. Devi M. Analisis faktor-faktor yang berpengaruh terhadap status gizi balita di pedesaan. Jurnal Teknologi dan Kejuruan. 2010; (33) 2: 183192.

7. Rahim F. Faktor risiko underweight balita usia 7-59 bulan. Jurnal KESMAS. 2014; (2) 9: 115121.

8. Permatasari D. Perbedaan durasi penyembuhan diare dehidrasi ringan-sedang balita yang diberikan ASI dan SENG di RSUP Dr. Kariadi. SKRIPSI Mahasiswa Universitas Diponegoro. 2012.

9. Giri M, Muliarta I dan Wahyuni N. Hubungan pemberian asi ekslusif dengan status gizi balita usia 6-24 bulan di Kampong Kajanan Buleleng. Jurnal SAINS dan Teknologi. 2013; (2) 1: 184192.

10. Zogara A, Hadi H, Arjuna T. Riwayat pemberian ASI eksklusif dan MPASI dini sebagai prediator terjadinya stunting pada baduta di Kabupaten Timur Tengah Selatan, Nusa Tenggara Timur. J Giz dan Diet Indones. 2014; 2(1): 41-50.

11. Handajani $S$ dan Ishartanti D. Pemberian air susu ibu (ASI) dan makanan pendamping ASI (MP-ASI) Lokal. Surakarta: Cakra Books. 2006.

12. Normayanti dan Susanti N. Status pemberian asi terhadap status gizi bayi usia $6-12$ bulan. Jurnal Gizi Klinik Indonesia. 2013; (9) 4: 155-161.

13. Nuryanto. Hubungan status gizi terhadap terjadinya penyakit infeksi saluran pernafasan akut (ISPA) pada balita di Palembang. Jurnal Pembangunan Manusia. 2012; (6) 2: 1-12.

14. Agus S, Handoyo, dan Widiyanti Dwi. Analisis faktor-faktor resiko yang mempengaruhi kejadian diare pada balita di Puskesmas Ambal 1 Kecamatan Ambal Kabupaten Kebumen. Jurnal IImiah Kesehatan Keperawatan. 2009; (5) $2: 65-79$.

15. Febrianto W, Mahfoedz I, Mulyanti. Status gizi berhubungan dengan kejadian ISPA pada balita di Wilayah Kerja Puskesmas Wonosari I Kabupaten Gunungkidul 2014. J Giz dan Diet Indones. 2015; 3(2): 113-8

16. Tando N. Durasi dan frekuensi sakit balita dengan terjadinya stunting pada anak SD di Kecamatan Malalayang Kota Manado. Jurnal Gizido. 2012; (4) 1 : 338-48.

17. Rosari A, Rini E dan Masrul. Hubungan diare dengan status gizi balita di Kelurahan Lubuk Buaya Kecamatan Koto Tangah Kota Padang. Jurnal Kesehatan Andalas. 2013; (3) 2: 11115. 